\title{
BINARY ACTION OF CHLORPYRIFOS-METHYL AND METHOPRENE ON THE LARVAL BIOCHEMISTRY OF ALMOND MOTH, EPHESTIA CAUTELLA WALKER (LEPIDOPTERA:PYRALIDAE)
}

\author{
Awanish Chandra and S.K. Tiwari ${ }^{1}$ \\ Department of Zoology \\ D.D.U. Gorakhpur University, Gorakhpur- 273 009, India \\ ${ }^{1}$ Corresponding author: sktzddu@ rediffmail.com
}

\begin{abstract}
Sub-lethal concentrations i.e. 1,2 and 4 ppm mixture of chlorpyrifos-methyl and methoprene in the ratio of 9:1 caused a significantly dose-dependent reduction in the levels of total protein, DNA, RNA and RNA/ DNA ratio and a significantly dose-dependent enhancement in the total free amino acid levels in haemolymph and fat body tissues of the larva of almond moth, Ephestia cautella Walker, a serious pest of stored cereals. The highest concentration ( $4 \mathrm{ppm}$ ) of this mixture caused abrupt changes in the metabolic framework of the larva that impairs its physiological fitness, which ultimately leads to death, if exposed to $8 \mathrm{ppm}$ concentration of this binary mixture. The present study states that methoprene enhances the toxicodynamic property of chlorpyrifos-methyl in a synergistic way.
\end{abstract}

KEYWORDS: Ephestia cautella, haemolymph, fat body, biochemistry, chlorpyrifos-methyl, methoprene

\section{INTRODUCTION}

Post-harvest losses and quality deterioration due to storage pests are a major problem throughout the world. The almond moth, Ephestia cautella (Walker) is a notorious pest of stored cereals and cereal commodities in India as well as throughout tropical and temperate regions of the world $^{12,65,51}$. Its larval stages cause serious damage to wheat, maize, ground nuts, pulses, peanuts and beans etc ${ }^{5,56,51,3}$.

Considerable measures have been adopted in relation to application of organic pesticides since World War II, which brought inestimable benefits to humanity in terms of human lives saved, diminished sufferings, and economic gain ${ }^{61,45}$. but continuous tremendous use of organic pesticides, since last four decades, has polluted the whole environment in addition to causing adverse effect on non- target organisms like parasites, predators and pollinators. They have also posed serious problems like bioaccumulation and development of insecticide resistance. So, there is urgent need of safe and suitable insecticides for the efficient control of almond moth, Ephestia cautella in particular and lepidopterous pests in general.

Chlorpyrifos-methyl exposure has shown good result against rice weevil, Sitophilus oryzae (L.); granary weevil, $S$. granarius (L.); maize weevil, S. zeamais Motschulsky; lesser grain borer, Rhyzopertha dominica (Fabricius); $T$. confusum and $T$. castaneum $^{39}$. It was also found to be effective against khapra beetle, 
Trogoderma granarium Everts and $T$. confusum in wheat grain ${ }^{25}, \quad P$. interpunctella ${ }^{6}$ and lesser grain borer, Rhyzopertha dominica ${ }^{31}$ (Fabricius). In mammals chlorpyrifos-methyl is rapidly absorbed and metabolized, the principal metabolite being 3, 5, 6-trichloro-2-pyridol. The present compound and metabolite are excreted primarily in the urine and faeces and are not stored to any extent in the body $^{42}$. It has lower mammalian toxicity, $\mathrm{LD}_{50}$ (oral, rat) $3000 \mathrm{mg} / \mathrm{kg}$. Its limited environmental persistence and lack of cross resistance makes chlorpyrifos-methyl a more attractive prospect than DDT for indoor residual spraying ${ }^{68}$ (Tomlin, 2000).

Development of insecticide resistance in insects is a great concern and to overcome such problem mixtures of certain insecticides having different mode of action can be used to nullify each others resistance. Application of insect growth regulators mixed with synthetic organic insecticides has shown to be a suitable alternative to suppress the development of such resistance.

Insect growth regulators (IGRs) also called "Third-Generation Pesticides", mimic insect's hormone and regulate the insect population through the disruption of moulting and metamorphosis ${ }^{73,49}$. They have a good margin of safety for most non-target biota, as they display a very low toxicity for human and other mammals, are readily biodegradable (i.e. very low persistence in the environment), highly toxic to target insects, and leave no hazardous residues, making JHAs very useful in food preservation and storage ${ }^{70}$. It has been useful in combinations with other neurotoxic pesticides particularly for control of pest species that have developed resistance to such pesticides.

Methoprene is a long chain hydrocarbon ester considered to have higher potency and better field stability than do naturally occuring juvenile hormone ${ }^{32}$. It is a selective, stable and potent larvicide; an ether and diunsaturated fatty acid ester; and its toxicity to insects is to manifest through interference with metamorphosis, a process without parallel in mammals. It is nonpersistent and non-toxic to mammals and presents no long-term hazards to other species at recommended application rates.

The prolongation of larval life presents a distinct disadvantage to using IGRs as a means of controlling stored product insects ${ }^{64}$ but binary approach of IGRs with certain reduced risk insecticides may be considered to reduce the prolongation of larval life.

Several studies indicate that methoprene in combination with other reduced risk-insecticides can control stored grain insects, including those populations that are resistant to orgaophosphorous insecticides ${ }^{22,23,49,15}$.

The haemolymph is the only extracellular fluid in the insect body and haemocytes suspended in plasma serve principally in phagocytosis ${ }^{38}$. Hormones that regulate larval moulting, growth, longevity, metamorphosis, metabolism and reproductive behavior of insects are secreted 
and circulated in the haemolymph ${ }^{46,33}$. The plasma contains about $85 \%$ water, is usually slightly acidic and includes inorganic ions, plenty of amino acids, proteins, fats, sugars, organic acids in variable amounts ${ }^{74,21,29}$. It provides a store of water on which the tissue can draw during desiccation and in some cases acts as an appreciable organ of storage for food. It also transports food materials and hormones and exerts a mechanical function in the eversion of protrusible structures.

The fat body, irregular masses or lobes of rounded or polyhedral cells (trophocytes) $^{52}$, is a dynamic tissue discharging a variety of important functions like storage of various nutrients, detoxification of foreign chemicals and biosynthesis of circulating metabolites like mammalian liver ${ }^{35}$. It maintains a constant exchange relation with haemolymph ${ }^{29}$.

Insecticides have shown to exert massive effect on the haemolymph and fat body biochemistry of insects ${ }^{48,55,34,4,66,67}$.

Juvenile hormone analogues (JHAs) have also been reported to influence the biochemistry of proteins ${ }^{75,47,27,30,71,18,19}$; amino acids $^{18,19}$ and nucleic acids ${ }^{24,60,69}$ in various tissues of insects that leads to metabolic perturbations and consequently biochemical lesion.

Scientific contribution in relation to binary action of synthetic organic insecticides and IGRs influencing haemolymph and fat body biochemistry of the larva of E. cautella is completely wanting. Hence, as an objective of such programme, the present work has been designed and conducted to examine into the impact of chlorpyriphos- methyl synergized with methoprene on the haemolymph and fat body biochemistry of the larva of almond moth, Ephestia cautella for its effective and safe control.

\section{MATERIALS AND METHOD}

The almond moth, Ephestia cautella (Walker) (Lepidoptera: Pyralidae) was collected from the go-downs of Central Warehouse Corporation, Nandanagar, Gorakhpur, U.P.; Food Corporation of India, Sardarnagar, Gorakhpur, U.P.; State Warehouse Corporation, Chauri Chaura, Gorakhpur, U.P. and State Warehouse Corporation, Sahjanwa, Gorakhpur, U.P.

A rich standard culture of this insect was maintained in the laboratory on a normal dietary medium composed of coarsely ground wheat (Triticum aestivum) mixed with $5 \%(\mathrm{w} / \mathrm{w})$ yeast powder and $10 \%$ (w/w) glucose inside large glass containers (150 $\mathrm{mm}$ diameter, $200 \mathrm{~mm}$ height) at a temperature of $26 \pm 1^{\circ} \mathrm{C}$, relative humidity $93 \pm 5 \%$ and a light regime of $12 \mathrm{hr}$ light and $12 \mathrm{hr}$ darkness.

From the above culture whenever needed, newly emerged males and females were transferred to oviposition glass chambers (35 mm diameter, $200 \mathrm{~mm}$ height). Since, E. cautella individuals do not feed during their adult stage, no food was provided to them during their confinement in these vessels. Eggs laid by the females 
were collected and then placed in glass chambers (consisting of $250 \mathrm{ml}$ beakers) for hatching.

A mixture of two insecticides i.e. chlorpyrifos-methyl (an organophosphate compound) and methoprene (a juvenile hormone analogue), in the ratio of 9:1 were utilized throughout the investigation.

Chlorpyrifos-methyl (0,0-dimethyl 0(3,5,6-trichloro-2-pyridyl), Molecular formula: $\mathrm{C}_{7} \mathrm{H}_{7} \mathrm{Cl}_{3} \mathrm{NO}_{3} \mathrm{PS}, 98.5 \%$ (a.i.) and methoprene (isopropyl (2E, 4E)-11methoxy-3, 7, 11- trimethyl-2-1,4dodecadienoate), Molecular formula: $\mathrm{C}_{19} \mathrm{H}_{34} \mathrm{O}_{3}$ (7.4\% cis and $90.4 \%$ trans) $97.8 \%$ (a.i.) used throughout the investigation were obtained from AccuStandard, Inc. 125 Market Street, New Haven, CT 06513 and have the following structural formula:<smiles>COP(=S)(OC)Oc1nc(Cl)c(Cl)cc1Cl</smiles>

Chlorpyrifos-methyl

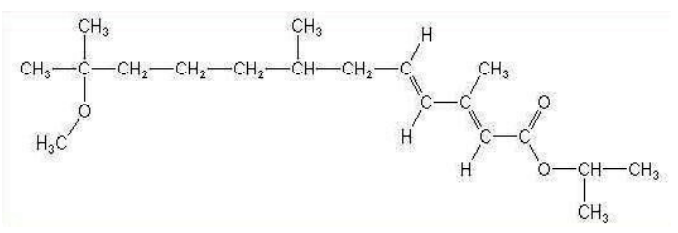

Methoprene

Toxicity results of methoprene ${ }^{16}$ (Chandra and Tiwari, 2013), chlorpyrifosmethy ${ }^{17}$ (Chandra and Tiwari,2014b) and their mixture ${ }^{20}$ in the ratio of 9:1 (Chandra and Tiwari, 2014d) against the ontogeny of
Ephestia cautella, at various dose levels have been reported.

For biochemical estimations, out of various concentrations of the mixture of chlorpyrifos-methyl + methoprene in ratio of 9:1, only such concentrations i.e. three from this mixture (1,2 and $4 \mathrm{ppm})$ were selected, which allowed the larvae to survive and develop but caused considerable effect in the internal biochemistry of the haemolymph and fat body tissues of the larva that could be easily detected and assessed to prove the effectiveness of this mixture as a chemical control measure against this lepidopterous pest.

For such purpose, freshly hatched larvae were allowed to feed on a normal dietary medium (kept inside $250 \mathrm{ml}$ beakers) for 13 days. On the $14^{\text {th }}$ day, 25 third instar larvae were transferred to each similar rearing chambers containing dietary medium mixed with 1, 2 and 4 ppm concentrations of the mixture of chlorpyrifos-methyl + methoprene in ratio of 9:1 and were allowed to feed for 10 days. 25 larvae were also kept as control with each set of experiment.

On the completion of 23 days, 10-15 larvae from each set, experimental as well as control, were taken out and their haemolymph and fat body tissues were separately collected (Krishna and Pandey, 1974) for biochemical assay ${ }^{37}$.

The total protein level was measured according to the method of Lowry et al. $(1951)^{44}$ using bovine serum albumin as standard while total free amino acids were 
determined according to the method of Spies $(1957)^{63}$ using glycine solution as standard. Deoxyribonucleic acid (DNA) and ribonucleic acid (RNA) levels were estimated according to the method of Schneider (1957) ${ }^{54}$ using calf thymus DNA and yeast RNA as standard for DNA and RNA respectively.

Results have been expressed as the mean \pm s.e. of six replicates. Significant differences between treatment groups, in order to show dose dependence, were determined by one way analysis of variance (one way ANOVA) ${ }^{62}$ (Sokal and Rohlf, 1969).

\section{RESULTS AND DISCUSSION}

Sub-lethal concentrations (1, 2 and $4 \mathrm{ppm}$ ) of the mixture of chlorpyrifos-methyl + methoprene in the ratio of $(9: 1)$ caused a significantly dose-dependent $(\mathrm{p}<0.001)$ reduction in the levels of total protein in haemolymph as well as in fat body (Table I). In the control larval groups, the total protein content was 54.865 and $67.784 \mu \mathrm{g} /$ $\mathrm{mg}$ in haemolymph and fat body respectively. The maximum decrease in total protein levels in haemolymph (31\% of the control value) and fat body (38\% of the control value) was observed in larvae treated with $4 \mathrm{ppm}$ concentration of the mixture. Protein levels, in haemolymph, were reduced to $70(38.649 \mu \mathrm{g} / \mathrm{mg}), 46(25.405$ $\mu \mathrm{g} / \mathrm{mg})$ and $31 \%(17.189 \mu \mathrm{g} / \mathrm{mg})$ of the control while these levels, in fat body, were reduced to $80(54.189 \mu \mathrm{g} / \mathrm{mg}), 54(36.487$ $\mu \mathrm{g} / \mathrm{mg})$ and $38 \%(25.892 \mu \mathrm{g} / \mathrm{mg})$ of the control value following treatment with 1,2 and $4 \mathrm{ppm}$ concentrations of the mixture respectively ( Table 1 ).

Table-1. Changes in the total protein levels in the haemolymph and fat body of the larva of E. cautella treated with the mixture of the chlorpyrifos-methyl + methoprene in the ratio $(9: 1)$

\begin{tabular}{|c|c|c|}
\hline \multirow{2}{*}{$\begin{array}{c}\text { Concentration of chlorpyrifos-methyl } \\
+ \text { methoprene (9:1)(ppm) }\end{array}$} & \multicolumn{2}{|c|}{ Total protein ${ }^{\#}(\boldsymbol{\mu g} / \mathbf{~ m g}$, wet wt.) } \\
\cline { 2 - 3 } & Haemolymph & Fat body \\
\hline Control (untreated) & $54.865 \pm 1.351(100)$ & $67.784 \pm 1.401(100)$ \\
\hline 1 & $38.649 \pm 1.285(70)$ & $54.189 \pm 1.034(80)$ \\
\hline 2 & $25.405 \pm 1.159(46)$ & $36.487 \pm 0.912(54)$ \\
\hline 4 & $17.189 \pm 0.799(31)$ & $25.892 \pm 0.564(38)$ \\
\hline
\end{tabular}

\#Values are expressed as the mean \pm s.e. of six replicates.

Values in the parentheses indicate the percentage change with control values taken as $100 \%$.

Analysis of variance showed that the response to the mixture of chlorpyrifos-methyl + methoprene $(9: 1)$ was dose-dependent $\mathrm{p}<0.001$. 
A significantly dose-dependent $(\mathrm{p}<$ 0.001 ) enhancement in the level of total free amino acids was recorded in haemolymph and fat body tissues of the larva of E. cautella following treatment with sub-lethal concentrations (1,2 and $4 \mathrm{ppm}$ ) of the mixture of chlorpyrifos-methyl + methoprene (9:1) ratio (Table 2).

In the control larval groups, the total free amino acids content was 68.503 and $12.245 \mu \mathrm{g} / \mathrm{mg}$ in haemolymph and fat body respectively. Larvae treated with $4 \mathrm{ppm}$ concentration of the mixture of chlorpyrifosmethyl + methoprene $(9: 1)$ ratio showed a maximum enhancement in the total free amino acids level in haemolymph (183\% of the control) and fat body (197\% of the control). Total free amino acids level, in haemolymph, were increased to $124(85.273$ $\mu \mathrm{g} / \mathrm{mg}), 151(103.223 \mu \mathrm{g} / \mathrm{mg})$ and $183 \%$ $(125.258 \mu \mathrm{g} / \mathrm{mg})$ of the control value while these levels, in fat body, were increased to $148(18.173 \mu \mathrm{g} / \mathrm{mg}), 182(22.271 \mu \mathrm{g} / \mathrm{mg})$ and $197 \%(24.145 \mu \mathrm{g} / \mathrm{mg})$ of the control value following treatment with 1,2 and 4 ppm concentrations of the mixture respectivel ( Table 2 ).

Table-2. Changes in the total free amino acids level in the haemolymph and fat body of the larva of E. cautella treated with the mixture of chlorpyrifos-methyl + methoprene in the ratio $(9: 1)$

\begin{tabular}{|c|c|c|}
\hline $\begin{array}{c}\text { Concentration ofchlorpyrifos-methyl } \\
+\end{array}$ methoprene $(9: 1)(\mathbf{p p m})$ & \multicolumn{2}{|c|}{ Total free amino acids ${ }^{\#}(\boldsymbol{\mu g} / \mathbf{~ m g}$, wet wt.) } \\
\cline { 2 - 3 } & Haemolymph & Fat body \\
\hline Control (untreated) & $68.503 \pm 1.477(100)$ & $12.245 \pm 0.491(100)$ \\
\hline 1 & $85.273 \pm 1.503(124)$ & $18.173 \pm 0.507(148)$ \\
\hline 2 & $103.223 \pm 2.975(151)$ & $22.271 \pm 1.541(182)$ \\
\hline 4 & $125.258 \pm 1.430(183)$ & $24.145 \pm 0.548(197)$ \\
\hline
\end{tabular}

\#Values are expressed as the mean \pm s.e. of six replicates.

Values in the parentheses indicate the percentage change with control values taken as $100 \%$.

Analysis of variance showed that the response to the mixture of chlorpyrifos-methyl + methoprene (9:1) was dose-dependent $\mathrm{p}<0.001$.

A significantly dose-dependent ( $\mathrm{p}<$ 0.01 ). reduction in the levels of DNA was recorded in haemolymph and fat body tissues of the larva following treatment with sub-lethal concentrations (1,2 and $4 \mathrm{ppm})$ of the mixture of chlorpyrifos-methyl + methoprene (9:1) ratio (Table 3).

In the control larval groups the deoxyribonucleic acid level was 9.615 and $6.255 \mu \mathrm{g} / \mathrm{mg}$ in the haemolymph and fat body respectively. Larvae treated with $4 \mathrm{ppm}$ 
concentration of the mixture of chlorpyrifosmethyl + methoprene $(9: 1)$ ratio showed a maximum decrease in the DNA level in haemolymph (59\% of the control value) and fat body (39\% of the control value). DNA levels, in haemolymph, were reduced to 87 $(8.384 \mu \mathrm{g} / \mathrm{mg}), 76(7.342 \mu \mathrm{g} / \mathrm{mg})$ and $59 \%$
(5.710 $\mu \mathrm{g} / \mathrm{mg})$ of the control value while these levels, in fat body, were reduced to $81(5.090 \mu \mathrm{g} / \mathrm{mg}), 66(4.105 \mu \mathrm{g} / \mathrm{mg})$ and $39 \%(2.428 \mu \mathrm{g} / \mathrm{mg})$ of the control value following treatment with 1,2 and 4 ppm concentrations of this mixture respectively (Table 3).

Table-3. Changes in the DNA levels in the haemolymph and fat body of the larva of $E$. cautella treated with the mixture of chlorpyrifos-methyl + methoprene in the ratio $(9: 1)$

\begin{tabular}{|c|c|c|}
\hline \multirow{2}{*}{$\begin{array}{c}\text { Concentration of chlorpyrifos-methyl } \\
+ \text { methoprene }(\mathbf{9 : 1})(\mathbf{p p m})\end{array}$} & \multicolumn{2}{|c|}{ DNA $(\boldsymbol{\mu g} / \mathbf{m g}$, wet wt.) } \\
\cline { 2 - 3 } & Haemolymph & Fat body \\
\hline Control (untreated) & $9.615 \pm 0.115(100)$ & $6.255 \pm 0.245(100)$ \\
\hline 1 & $8.384 \pm 0.124(87)$ & $5.090 \pm 0.119(81)$ \\
\hline 2 & $7.342 \pm 0.260(76)$ & $4.105 \pm 0.126(66)$ \\
\hline 4 & $5.710 \pm 0.361(59)$ & $2.428 \pm 0.132(39)$ \\
\hline
\end{tabular}

\#Values are expressed as the mean \pm s.e. of six replicates.

Values in the parentheses indicate the percentage change with control values taken as $100 \%$.

Analysis of variance showed that the response to the mixture of chlorpyrifos-methyl + methoprene $(9: 1)$ was dose-dependent $\mathrm{p}<0.01$.

In the control larval group, the ribonucleic acid content in the haemolymph and fat body was 14.496 and $9.921 \mu \mathrm{g} / \mathrm{mg}$ respectively. Sub-lethal concentrations (1, 2 and $4 \mathrm{ppm})$ of the mixture of chlorpyrifosmethyl + methoprene in the ratio $(9: 1)$ caused a significantly dose-dependent $(\mathrm{p}<$ 0.01 ) reduction in the levels of RNA in both the tissues of the larva (Table 4). The maximum decrease in RNA levels in haemolymph, (34\% of the control value) and fat body (29\% of the control value) was observed in larve treated with $4 \mathrm{ppm}$ concentration of the mixture of chlorpyrifosmethyl + methoprene $(9: 1)$ ratio. RNA levels, in haemolymph, were reduced to 75 $(10.895 \mu \mathrm{g} / \mathrm{mg}), 57(8.098 \mu \mathrm{g} / \mathrm{mg})$ and $34 \%$ $(4.988 \mu \mathrm{g} / \mathrm{mg})$ of the control value while these levels, in fat body, were reduced to $75(7.399 \mu \mathrm{g} / \mathrm{mg}), 52(5.109 \mu \mathrm{g} / \mathrm{mg})$ and $29 \%(2.913 \mu \mathrm{g} / \mathrm{mg})$ of the control value following treatment with 1,2 and $4 \mathrm{ppm}$ concentrations of this mixture respectively (Table 4).

RNA/DNA ratio, in control larvae, was 1.507 in haemolymph and 1.586 in fat body, when treated with sub-lethal concentrations of the mixture of chlorpyrifos-methyl + methoprene $(9: 1)$ ratio. The maximum decrease in this ratio in haemolymph $(58 \%$ 
Table-4. Changes in the RNA levels in the haemolymph and fat body of the larva of $E$. cautella treated with the mixture of chlorpyrifos-methyl + methoprene in the ratio $(9: 1)$

\begin{tabular}{|c|c|c|}
\hline $\begin{array}{c}\text { Concentration ofchlorpyrifos-methyl } \\
+ \text { methoprene (9:1) (ppm) }\end{array}$ & \multicolumn{2}{|c|}{ RNA ${ }^{\#}(\boldsymbol{\mu g} / \mathbf{m g}$, wet wt.) } \\
\cline { 2 - 3 } & Haemolymph & Fat body \\
\hline Control (untreated) & $14.496 \pm 0.276(100)$ & $9.921 \pm 0.215(100)$ \\
\hline 1 & $10.895 \pm 0.307(75)$ & $7.399 \pm 0.207(75)$ \\
\hline 2 & $8.098 \pm 0.274(57)$ & $5.109 \pm 0.136(52)$ \\
\hline 4 & $4.988 \pm 0.1 .63(34)$ & $2.913 \pm 0.227(29)$ \\
\hline
\end{tabular}

\#Values are expressed as the mean \pm s.e. of six replicates.

Values in the parentheses indicate the percentage change with control values taken as $100 \%$.

Analysis of variance showed that the response to the mixture of chlorpyrifos-methyl + methoprene $(9: 1)$ was dose-dependent $\mathrm{p}<0.01$.

Table-5. Alterations in the RNA/DNA ratio in haemolymph and fat body of the larva of E. cautella treated with the mixture of chlorpyrifos-methyl + methoprene in the ratio $(9: 1)$

\begin{tabular}{|c|c|c|}
\hline \multirow{2}{*}{$\begin{array}{c}\text { Concentration ofchlorpyrifos-methyl } \\
+ \text { methoprene }(\mathbf{p p m})\end{array}$} & \multicolumn{2}{|c|}{ RNA/DNA ratio } \\
\cline { 2 - 3 } & Haemolymph & Fat body \\
\hline Control (untreated) & $1.507(100)$ & $1.586(100)$ \\
\hline 1 & $1.299(86)$ & $1.454(92)$ \\
\hline 2 & $1.103(73)$ & $1.245(79)$ \\
\hline 4 & $0.813(58)$ & $1.190(75)$ \\
\hline
\end{tabular}

The values in the parentheses indicate the percentage change with control value taken as $100 \%$.

of the control value) and fat body (75\% of the control value) was observed in larvae treated with 4 ppm concentrationofthis mixture. The RNA/DNA ratios, in haemolymph, were reduced to 86 (1.299), $73(1.103)$ and $58 \%(0.813)$ of the control value while these ratios in fat body, were reduced to $92(1.454), 79(1.245)$ and $75 \%$ (1.190) of the control value following treatment with 1,2 and 4 ppm concentrations of this mixture respectively (Table 5).

The present investigation reveals some of the so far unexplored information regarding potential of a synergistic mixture of chlorpyrifos-methyl (an organophosphorus insecticide) and methoprene (a juvenile hormone analogue) in the ratio of 9:1 on the total protein, total free amino acids, DNA and RNA levels 
in the haemolymph and fat body tissues of the larva of almond moth, Ephestia cautella, pertaining to a specific age group. The findings are discussed here in the light of the influence of this synergistic mixture (in the ratio of 9:1) as insecticidal agents on the basic extrinsic as well as intrinsic cellular mechanisms such as transport, synthesis, degradation and storage in relation to the aforesaid biochemical constituents to come to some such conclusions which may in future help in devising ways and means for the effective control of this lepidopterous pest.

Proteins are among the most complex of all known chemical compounds and also the most characteristic of living organism. They serve as an important internal environmental factor for the metabolism, especially having a close relation with fat body, metamorphic hormone, trehalose and sex hormone during development and metamorphosis ${ }^{41}$. Protein synthesized in the early instars of the larval fat body (the main site of protein synthesis of blood protein) are subsequently released into the surrounding blood ${ }^{57}$, which, in later instars are sequestered from the blood into the fat body. Regarding their synthesis, it was observed that in fruit fly, Drosophila amino acids $^{59}$ are first incorporated into peptides and later enter into proteins ${ }^{72}$. Higher concentrations of insecticides inhibit amino acid incorporation into protein causing adverse effect on protein biosynthesis ${ }^{1}$.

In the present investigation, all the three sub-lethal concentrations of the mixture of chlorpyrifos-methyl and methoprene (9:1) ratio caused a significantly dose-dependent $(\mathrm{p}<0.001)$ reduction in the level of total protein in both the tissues of the larva (Table 1). Similar to this observation, application of sub-lethal doses of organophosphorous insecticides reduced the protein content in the haemolymph of gypsy-moth, Porthetria dispar ${ }^{48}$ caterpillars, and BHC ( a chlorinated insectide) reduced the protein content in haemolymph of German cockroach, Blattella germanica ${ }^{41}$. On the contrary, lower DDT concentrations increased the protein content of Triatoma infestans by enhancing the amino acid incorporation into protein while higher DDT concentrations inhibited the amino acid incorporation into protein causing adverse effect on protein biosynthesis ${ }^{1}$. Application of a mixture of chlorpyrifos and camphor extract significantly decreased the total protein level by $13.5 \%$ in the larva of cotton leafworm, Spodoptera littoralis while this level was reduced to 31 and $26 \%$ following the exposure of camphor extract and chlorpyrifos repectively ${ }^{50,28}$. In addition, exposure of chlorosan (chloropyrifos $24 \%$ + cypermethrin 5\%), engeo (thiamethoxam $14.1 \%$ + lambda-cyclithrin $10.6 \%$ ), cygron (flufenoxuron 3\% + alpha-cypermethrin7\%) and feroban (chloropyrifos $47.5 \%+$ lufenuron $2.5 \%$ ) caused significant reduction in total protein level in the larva of $S$. littoralis ${ }^{26}$. Our present findings are in accordance with the above results as reported in case of $S$. littoralis ${ }^{26,28,50}$. It appears that reduction in protein level in 
haemolymph and fat body, in the present study, may be due to the insecticidal ( chlorpyrifos-methyl+ methoprin ) inhibition of amino acid incorporation into protein, as reported in case of Triatoma infestans ${ }^{1}$ in relation to higher DDT concentration.

One of the most characteristic features of insect haemolymph is the high level of free amino acids $^{72,21,29}$ whereas insect fat body is an active site for the intermediary metabolism of these amino $\operatorname{acids}^{35,21}$. The high concentration of free amino acid is believed to play an important role in osmoregulation $^{11,8}$, buffering of the blood to some extent, energy production for flight and cocoon construction ${ }^{74}$, with the predominant function of serving as units for protein synthesis ${ }^{14}$ and taking part in other metabolic activities.

In the present study, the sub-lethal concentrations of chlorpyrifos-methyl + methoprene (9:1) caused a significantly dose-dependent $(\mathrm{p}<0.001)$ enhancement in the level of total free amino acids in both the tissues of the larva of this pest (Table 2). Similar result has also been reported in case of $T$. castaneum larvae following exposure of binary mixture of permethrin $(200 \mathrm{ppm})$ and malathion (20 $\mathrm{ppm})^{55}$. Since chlorpyrifos-methyl+ methoprene, in the present study, decreased the protein level in haemolymph and fat body of the larva of almond moth as stated above, it may be concluded that a rise total free amino acid level in both the tissues is plausibly on account of protein depletion and/or inhibition of amino acid incorporation into proteins.

RNA content can be considered an index of the capacity of organism for protein synthesis where as DNA content provides an estimate of cell number. The RNA/DNA ratio is, therefore, a measure of protein synthetic capacity per cell ${ }^{13,40}$.

Insecticides have shown to alter the nucleic acid levels in various tissues of insects ${ }^{9,36,10,58}$. Literatures concerning insecticidal induced changes in the nucleic acid levels with special reference to insects $^{7,43}$ are far from adequate.

In the present investigation binary mixture of chlorpyrifos-methyl and methoprene caused a dose-dependent $(\mathrm{P}<$ $0.01)$ reduction in the levels of DNA and RNA (Table 3 and 4) and a significant reduction in RNA/DNA ratio (Table 5) in both the tissues of the larva of this pest. Similarly, DDT and dieldrin have been shown to reduce the nucleic acids as well as protein content in rats ${ }^{9,36}$ but DDT stimulated RNA synthesis in adult houseflies, Musca domestica ${ }^{7}$ and in nymphs of Triatoma infecstans ${ }^{43}$. Organophosphorus compounds have been reported to be a strong inhibitor of nucleic acids ${ }^{10}$. They interfere with the synthesis site of nucleic acids as reported in the fish Tilapia mossambica ${ }^{53}$ exposed to DDVP. Similar explanation for decrease in DNA and RNA contents have also been reported in BHC fed rats ${ }^{58}$. Pesticides induced DNA damage have also been reported in human cell culture $^{2}$. The reduction in the DNA and RNA levels, in the present study, may be due to 
interference of this binary mixture (Chlorpyrifos-methyl methoprene in the ratio of 9:1) with the synthesis site of nucleic acids. As stated earlier, the two parameters- RNA content and RNA/DNA ratio, show a significant correlation with protein content. Thus, the protein content depends on its synthesis in which RNA plays a vital role. Data in the present study also demonstrate the reduction in the total protein level in both the tissues of the larvae following treatment with this binary mixture. Therefore, it may be presumed that the synthesis of protein is inhibited due to inhibition of RNA. It may also be presumed that reduction in protein levels is due to interference of this binary mixture (Chlorpyrifos-methyl and methoprene in the ratio of 9:1) with the transport of amino acids incorporation into the polypeptide chain. The enhancement in total free amino acid level further supports the above presumption.

The entire findings of the present investigation i.e. decreased protein level, increased amino acid titre and reduced DNA, RNA and RNA/DNA ratio leads to metabolic perturbation and consequently biochemical lesion in the chlorpyrifosmethyl + methoprene exposed larvae resulting into death. Application of a little amount of methoprene to the chlorpyrifosmethyl explores dual significance i.e. it enhances the activity of chlorpyrifos-methyl as synergist and reduces resistance in $E$. caulella, due to their different mode of action.

\section{ACKNOWLEDGEMENTS}

Authors are thankful to Prof. Rajendra Singh, former Head of Department of Zoology, DDU Gorakhpur University, Gorakhpur for providing laboratory facilities, and Prof. Ajai Singh \& Prof. V.B. Kushwaha for critical review of the manuscript. Thanks are also due to AccuStandard, Inc.125 Market Street, New Haven, CT 06513 for providing technical grade pesticides.

\section{REFERENCES}

1. Agosin, M., L. Aravena and A. Neghme, 1965. Enhanced protein synthesis in Triatoma infestans treated with DDT. Exp. Parasitol., 16(3): 318-324.

2. Ahmad, F.E., R.W. Hart and N.J. Lewis, 1977. Pesticide induced DNA damage and its repair in cultured human cells. Mut.Res.,42:161173

3. Akinneye, J.O. and O.C. Ogungbite, 2013. Effect of seed extracts of five indigenous plants against the stored product moth, Ephestia cautella (Walker) (Lepidoptera: Pyralidae) Arch. Phytopathol. Plant Prot., 46(12): 14881496.

4. Ali, N.S., S.S. Ali and A.R. Shakoori, 2013. Effects of sublethal doses of malathion on biochemical components of malathionresistant and -susceptible adults of Rhyzopertha dominica. Pak. J. Zool., 45(1): 203-212.

5. Anderbrant, O., C. Ryne, P.O. Christian Olsson, E. Jirle, K. Johnson and C. Löfstedt, 2007. Pheromones and kairomones for detection and control of indoor pyralid moths. Integr. Prot. Stored Prod. IOBC/wprs Bull., 30(2): 73-77

6. Arthur, F.H., 1989. Pests of stored peanuts: toxicity and persistence of chlorpyrifosmethyl. J. Econ. Entomol., 82(2): 660-664. 
7. Balazs, I. and M. Agosin, 1968b. The effect of 1, 1, 1-Trichloro-2, 2-bis (p-chlorophenyl) ethane on ribonucleic acid metabolism in Musca domestica L. Biochem. Biophy. Acta., 157: 1-7.

8. Beadle, L. and J. Shaw, 1950. The retention of salt and the regulation of the NPN fraction in the blood of the aquatic larva, Sialia lutaria. J. Exp. Biol., 127: 96-109.

9. Bhatia, S.C., S.C. Sharma and T.A. Venkitsubramanian, 1973. Effect of dieldrin on hepatic carbohydrate metabolism and protein biosynthesis in vivo. Toxicol. Appl. Pharmcaol., 24: 216.

10. Bhunya, S.P. and N. Das, 1976. Effect of a synthetic insecticide, dimethoate, on spermatocytic chromosomes of a shorthorned grasshopper, Poecilocerus pictus. Sci. and Cult., 42: 571.

11. Bishop, G.H., 1923. Body fluids of honey bee larva. I. Osmotic pressure, specific gravity, $\mathrm{pH}, \mathrm{O}_{2}$, capacity, $\mathrm{CO}_{2}$ capacity, and buffer value, and changes with larval activity and metamorphosis. J. Biol. Chem., 58: 543-565.

12. Boshra, S., 2007. Effect of gamma irradiation on food consumption, assimilation and digestive enzymes in Ephestia cautella (Walker) larvae. J. Stored. Prod. Res., 43(1): 49-52.

13. Brachet, J., 1955. In: The Nulcliec Acids. Vol. II, Academic Press, New York.

14. Buck, J.B., 1953. The internal environment in regulation and metamorphosis. In: Insect Physiology. Roeder, K. (ed.), Wiley, New York, pp. 191-217.

15. Chanbang, Y., F.H. Arthur, G.E. Wilde and J.E. Throne, 2007. Efficacy of diatomaceous earth and methoprene, alone and in combination, against Rhyzopertha dominica (F.) (Coleoptera: Bostrychidae) in rough rice. $J$. Stored Prod. Res., 43: 396-401.

16. Chandra, A. and S.K. Tiwari, 2013. Insecticidal effect of methoprene on the pre-adult stages of almond moth, Ephestia cautella Walker (Lepidoptera: Pyralidae). J. Biol. Earth Sci.,
3(2): 269-274.

17. Chandra, A. and S.K. Tiwari, 2014a. Effects of chlorpyrifos-methyl against the third-instar larvae of almond moth, Ephestia cautella (Walker) (Lepidoptera: Pyrelidae). Acad. J. Entomol., 7 (4): 140-144.

18. Chandra, A. and S.K. Tiwari, 2014b. Influence of chlorpyrifos-methyl on the biochemistry of haemolymph and fat body of the larva of almond moth, Ephestia cautella Walker (Lepidoptera: Pyralidae). Front. Biol. Life Sci., 2(4): 85-89.

19. Chandra, A. and S.K. Tiwari, 2014c. Influence of methoprene on the larval biochemistry in haemolymph and fat body of Ephestia cautella (Walker) (Lepidoptera: Pyralidae). J. Biol. Earth Sci., 4 (2): B185-B190.

20. Chandra, A. and S.K. Tiwari, 2014d. Synergistic action of chlorpyrifos-methyl and methoprene against the ontogeny of almond moth, Ephestia cautella (Walker) (Lepidoptera: Pyralidae). J. Appl. Biosci., 40(1): 57-62.

21. Chen, P.S., 1966. Amino acid and protein metabolism in insect development. In: Advances in Insect Physiology. Beament J.W.L., J.E. Treherne and V.B. Wigglesworth (eds). Vol. 3, Academic Press, New York, pp. 53-132.

22. Daglish, G.J., M. Eelkema and L.M. Harrison, 1995. Chlorpyrifos-methyl plus either methoprene or synergized phenotrin for control of Coleoptera in Queesland, Australia. J. Stored Prod. Res., 31(3): 235-241.

23. Daglish, G.J., 1998. Efficacy of six grain protectants applied alone or in combination against three species of Coleoptera. J. Stored Prod. Res., 34(4): 263-268.

24. Dhadialla, T.S., K.E. Cook and G.R. Wyatt, 1987. Vitellogenin mRNA in locust fat body: Coordinate induction of two genes by a juvenile hormone analog. Dev. Biol., 123(1): 108-114.

25. El-Bakary, A.S., 1994. Residues of chlorpyrifosmethyl on wheat grains, and its effect on certain stored-grain insects. J. King Saud Uni. 
Agric. Sci., 6(2): 331-336.

26. El-Mageed, A.E.M. and S.E.M. Shalaby, 2011. Toxicity and biochemical impacts of some new insecticide mixtures on cotton leafworm Spodoptera littoralis (Boisd.). Plant Protect. Sci., 47(4): 166-175.

27. Etebari, K., A.R. Bizhannia, R. Sorati and L. Matindoost, 2007. Biochemical changes in haemolymph of silkworm larvae due to pyriproxyfen residue. Pestic. Biochem. Physiol., 88(1): 14-19.

28. Fetoh, B.E.S.A. and K.A. Asiry, 2013. Biochemical effects of chlorpyrifos organophosphorous insecticide, camphor plant oil and their mixture on Spodoptera littoralis (Boisd.). Arch. Phytopath. Plant Prot., 46(15): 1848-1856.

29. Florkin, M. and C. Jeuniaux, 1974. Haemolymph: Composition. In: The Physiology of Insects, Rockstein, M. (ed.). Vol. 5, Academic Press, New York, pp. 255307

30. Ghasemi, A., J. Sendi and M. Ghadamyari, 2010. Physiological and biochemical effect of pyriproxyfen on Indian meal moth Plodia interpunctella (Hubner) (Lepidoptera: Pyralidae). J. Plant Prot. Res., 50(4): 416422.

31. Guedes, R.N.C., B.A. Dover and S. Kambhampati, 1996. Resistance to chlorpyrifos-methyl, pirimiphos-methyl, and malathion in Brazilian and U.S. populations of Rhyzopertha dominica (Coleoptera: Bostrichidae). J. Econ. Entomol., 89(1): 2732.

32. Henrick, C.A., W.E. Willy and G.B. Stall, 1976. Insect juvenile hormone activity of alkyl (2E, 4E)-3, 7, 11-trimethyl-2, 4dodecadienenoates. Variations in the ester function and in the carbon chain. J. Agric. Food Chem., 24(2): 207-218.

33. Hietakangas, V., \& S.M. Cohen 2009. Regulation of tissue growth through nutrient sensing. Annual Review Genetics, 43: 389-410. doi: 10.1146/annurev-genet-102108-134815.
34. Jangir, N. and S. Bakshi, 2012. Biochemical assimilations in the gonads of Chrotogonus trachypterus (Blanchard) (Orthoptera: Acrididae) exposed to sublethal dose of chlorpyrifos and fenvalerate. Pak. Entomol., 34(2): 137-143.

35. Kilby, B.A., 1963. The biochemistry of the insect fat body. Adv. Insect Physiol., 1: 111-174.

36. Kohli, K.K., S.C. Sharma, S.C. Bhatia and T.A. Venkatsubramaniam.1975. Biocheimcal effects of chlorinated insecticides DDT and dieldrin. J. Sci. Ind. Res., 34: 452.

37. Krishna, S.S. and G.C. Pandey, 1974. In Vivo studies on the fate of certain carbohydrates in the alimentary canal and haemolymph of the larva of Earias fabia Stoll (Lepidoptera: Noctudiae). New Entomol., 23: 1-7.

38. Krzemien, J., M. Crozatier and A. Vincent, 2010. Ontogeny of the Drosophila larval hematopoietic organ, hemocyte homeostasis and the dedicated cellular immune response to parasitism. The International Journal of Developmental Biology, 54: 1117- 1125.

39. LaHue, D.W., 1977. Chlorpyrifos-methyl: doses that protect hard winter wheat against attack by stored-grain insects. J. Econ. Entomol., 70(6): 734-736.

40. Lang, C.A., H.Y. Lau and D.J. Jefferson, 1965. Protein and nucleic acid changes during growth and aging in the mosquito. Biochem. J., 95: 372-377.

41. Lee, J.J., K.R. Lee and J.C. Shim, 1981. The effect of insecticides on haemolymph in the German cockroach, Blattela germanica L. Korean J. Entomol., 9(1): 25-32.

42. Lewerenz, H.J., 1977. Pesticide Residues in Food. Report of the 1975 Joint FAO/WHO Meeting. World Health Organization, Technical Report Series Nr. 592, Geneva. Preis: 6,- Sfr. Nahrung, 21(6): 555.

43. Litvak, S., L.T. Litvak, P. Poblete and M. Agosin, 1968. Evidence for the DDT-induced synthesis of messenger ribonucleic acid in Triatoma infestans. Comp. Biochem. Physiol., 26(1): 45-56. 
44. Lowry, O.H., N.J. Rosenbrough, A.L. Farr and R.J. Randall, 1951. Protein measurement with the Folin phenol reagent. J. Biol. Chem., 193: 265-275.

45. Metcalf, R.L., 1967. Mode of action of insecticide synergists. Ann. Rev. Entomol., 12(1): 229-256.

46. Mirth, C.K. and L.M. Riddiford, 2007. Size assessment and growth control: how adult size is determined in insects. Bioessays, 29(4): 344-355.

47. Mohan, K.G. and D. Muraleedharan, 2005. Modulatory influence of juvenile hormone analogue (JHa) and 20-hydroxyecdysone on lipophorin synthesis in red cotton bug, Dysdercus cingulatus Fabr. Indian J. Exp. Biol., 43(12): 1176-1181.

48. Molchanov, M.I., F.S. Kuteev, V.A. Molchanova and V.V. Nikiforov, 1980. The influence of organophosphorus insecticides on proteins in the haemolymph of gypsy moth caterpillars. Appl. Biochem. Microbiol., 16(5): 548-554.

49. Oberlander, H., D.L. Silhacek, E. Shaaya and I. Ishaaya, 1997. Current status and future perspectives of the use of insect growth regulators for the control of stored product insects. J. Stored Prod. Res., 33(1): 1-6

50. Osman, H.H., B.E.S.A. Fetoh and A.M. Mohammad, 2012. The potency of chloropyrifos and camphor extract on Spodoptera littoralis (BOISD.). Egypt. Acad. J. Biol. Sci., 5(2): 131-139.

51. Oyedokun, A.V., A.A. Omoloye and F.A. Okelana, 2012. Assessment of the influence of artificial dietary supplements on aspects of biology of adult cocoa moth, Ephestia cautella. IOSR J. Pharm. Biol. Sci., 3(6): 25-30.

52. Price, G.M., 1973. Protein and nucleic acid metabolism in insect fat body. Biol. Rev., 48(3): 333-375.

53. Rath, S. and B.N. Mishra. 1980. Changes in nucleic acids and protein contents of Tilapia mossambica exposed to dichlorvos (DDVP). India J. Fish., 27: 76-81.
54. Schneider, W.C., 1957. Determination of Nucleic Acids in tissues by Pentose Analysis. In: Methods in Enzymology. Colowick, S.P. and N.O. Kaplan (eds.), Academic Press, New York, pp. 680-684.

55. Shakoori, A.R. and M.A. Saleem, 1989. Some macromolecular abnormalities developed by the interaction of malathion and permethrin and subsequent refeeding in Tribolium castaneum larvae. Arch. Insect Biochem. Physiol., 11: 203-215.

56. Shehu, A., D. Obeng-Ofori and V.Y. Eziah, 2010. Biological efficacy of CalneemTM oil against the tropical warehouse moth Ephestia cautella (Lepidoptera: Pyralidae) in stored maize. Inter. J. Trop. Insect Sci., 30(4): 207213.

57. Shigematsu, H., 1960. Protein metabolism in the fat body of the silk worm, Bombyx mori L. Bull. Seric. Exp. Sta., Japan, 16: 141-70.

58. Shivanandappa, T. and M.K. Krishnakumari, 1981. Histochemical and biochemical changes in rats fed dietary BHC. Indian $J$. Exp. Biol., 19(12): 1163-1168.

59. Simmons, J.R. and H.K. Mitchell, 1962. Metabolism of peptides in Drosophila. In: Amino acid pools. Holden J.T. (ed.). Elsevier: Amsterdam, pp. 147-155.

60. Singh, A., 2015. Physiological and biochemical effects of fenoxycarb, a juvenile hormone analogue on the rice moth, Corcyra cephalonica Stainton (Lepidoptera: Pyralidae). Ph.D. Thesis, Department of Zoology, D.D.U. Gorakhpur Uni. Goralkpur, (U.P.)

61. Smith, F.R. \& R. van den Bosch., 1967. Integrated Control. In: Pest Control: Biological, Physical and Selected Chemical Method. Kilgore W.W. and R.L. Doutt (eds.), Academic Press, New York, pp. 295-340.

62. Sokal, R.R. and F.J. Rohlf, 1969. Biometry: the principles and practice of statistics in biological research. San Francisco: W.H. Freeman, pp. 776.

63. Spies, J.R., 1957. Colorimetric procedures for 
amino acids. In: Methods in Enzymology. Colowick, S.P. and N.O. Kaplan (eds.), Academic Press, New York, pp. 464-471.

64. Sutton, A.E., 2009. Residual toxicities of synergized pyrethrins and methoprene applied as aerosol insecticides. Doctoral dissertation, Kansas State Uni.

65. Temerak, S.A., 2010. Attraction of the almond moth, Cadra cautella (Walker), to ready made tea or coffee. An alternation method of methyl bromide in storehouses of date fruit in Egypt. IV Int. Date Palm Conf., Acta Hort. (ISHS), 882: 563-568.

66. Tiwari, S.K., 1987. Studies on the effect of certain insecticides on the chemistry of haemolymph and fat body of the larva of rice-moth, Corcyra cephalonica Stainton (Lepidoptera: Pyralidae). Ph.D. Thesis, Dept. of Zoology, Gorakhpur Univ. Gorakhpur, U.P. India.

67. Tiwari, S.K. and C.P.M. Tripathi, 2005. BHC and malathion induced changes in nucleic acids level in haemolymph and fat body of the larva of rice-moth, Corcyra cephalonica Staint. (Lepidoptera: Pyralidae). J. Adv. Zool., 26(2): 69-72.

68. Tomlin, C.D.S., 2000. The Pesticide Manual, Twelfth Edition, British Crop Protection Council World Health Organisation 1997. Guidelines for predicting dietary intake of pesticide residues. Document WHO/FSF/ FOS/97.7, 2nd rev. ed., Geneva.
69. Tripathi, P., 2015. Effect of methoprene, an insect growth regulator, on the reproductive biology of rice moth, Corcyra cephalonica Staint. (Lepidoptera: Pyralidae). Ph.D. Thesis, Department of Zoology, D.D.U. Gorakhpur University, Goralkpur, (U.P.)

70. Tunaz, H. and N. Uygun, 2004. Insect Growth Regulators for Insect Pest Control. Turk. J. Agric. For, 28(6): 377-387.

71. Uranli, R., E. Goncu and O. Parlak, 2011. Investigation of the influence of the juvenile hormone analogue fenoxycarb on major hemolymph proteins of the silkworm Bombyx mori during the last larval instar. Tourk. J. Zool., 35(2): 223-236.

72. Weinmann, H.P., 1964. Untersuchungen mit markierten Aminosauren Zum Proteinstoffwechsel normaler und letaler Genotype von Drosophila melanogaster. Z. Vergl. Physiol., 48: 429-461.

73. Williams, C.M., 1956. The juvenile hormone of insects. Nature, 178: 212-213.

74. Wyatt, G.R., 1961. The biochemistry of insect hemolymph. Ann. Rev. Entomol., 6: 75-102.

75. Wyatt, G.R., M.R. Kanost, B.C. Chin, K.E. Cook, B.M. Kawasoe and J. Zhang, 1992. Juvenile hormone analog and injection effects on locust hemolymph protein synthesis. Arch. Insect Biochem. Physiol., 20(3): 167-180. 